\title{
The Consequences of Perceived Risk in Electronic Government Service
}

\author{
Margaretha Pink Berlianto ${ }^{1}$, Farida Jasfar ${ }^{2}$, Hamdy Hady ${ }^{3}$, and Willy Arafah ${ }^{4}$ \\ \{Margaretha.berlianto@uph.edu ${ }^{1}$ \} \\ ${ }^{1}$ Department of Management, Pelita Harapan University, Karawaci, Indonesia \\ ${ }^{2}$ Department of Management, Trisakti University, Jakarta, Indonesia \\ ${ }^{3}$ Department of Magister Management, Persada Indonesia YAI University, Jakarta, Indonesia \\ ${ }^{4}$ Department of Magister Management, Trisakti University, Jakarta, Indonesia
}

\begin{abstract}
This study aims to investigate the effect of the dimensions of perceived risk namely performance, privacy, social, time, and financial audit risk on satisfaction, and to investigate the effect of satisfaction on trust in the context of e-government. There were 6 hypotheses developed in this study. This study was conducted using survey questionnaire data in Jakarta, Tangerang, Depok, Bekasi and Bogor area. The findings of this study are privacy and time risk has a negative effect on satisfaction and the satisfaction has a positive effect on trust. Performance, social, and financial audit risk have no effect on satisfaction.
\end{abstract}

Keywords: Perceived risk, satisfaction, trust, e-government.

\section{Introduction}

Nowadays, electronic service or known as e-service through the internet has a great impact on business transformation, not only in business operation but also in government operations, such as reducing the organization's operation cost. Besides its benefits, electronic service also entails greater risk to online users, such as distrust of electronic service provider and security concerns (Rotchanakitumnuai 2008). There is one risk as the most reasons by online users for not making transactions via internet channel and delay the adoption of electronic government service is perceived risk (Rotchanakitumnuai 2008). The customer also concern when purchasing an item via the internet because its full of uncertainty (Shukla 2014). Therefore, to encounter this risk, it is important for an organization to create trust in online purchasing (Papadopoulou et al. 2001). The previous study showed e-satisfaction has been found as one of the factors enhancing e-trust (Horppu, Kuivalainen, Tarkiainen \& Ellonen 2008).

Rotchanakitumnuai (2008) proposed five dimensions of perceived risk, namely time risk, financial audit, privacy, social, and performance risk, which formed e-government service risk. This study continues the limitation of Rotchanakitumnuai (2008)'s study, which suggests to carry out on a quantitative study to strengthen existing research and developed this research by including the trust as a new variable. Based on a literature search on previous research about perceived risk on electronic government service, it is found little-published research on this area and this model of e-perceived risk are conceptualized in different ways and have found little consensus. Therefore, this study aims to (1) investigate the effect of the dimensions of perceived risk introduced by Rotchanakitumnuai (2008) namely time, financial audit, privacy, social, and performance risk on satisfaction, (2) to investigate the effect of satisfaction on trust on the context of e-government. 


\section{Literature Review}

\subsection{Satisfaction}

In online buying, customers may feel satisfied when the things they purchased can be delivered with efficiency and the website design saves their time, easy to use and provide a variety of information. Anderson \& Srinivasan (2003, p. 125) defined e-satisfaction is "the contentment of customer with respect to his or her prior purchase experience with a given electronic commerce firm." Website satisfaction also could be referred to as the accomplishment of user's needs and expectation and overall perceived satisfactory on the website (Cyr et al. 2008).

\subsection{Perceived Risk}

Perceived risk has been known as a factor that has a great impact on electronic service acceptance (Rotchanakitumnuai 2008) and also as the main barrier toward acceptance of technology (Featherman \& Pavlou 2003). Consumers may not purchase or adopt a product or service if they perceived a high risk on the product or service (Rotchanakitumnuai, 2008). Perceived risk defined as the risk of exposing and losing personal information through online interaction (Warkentin et al. 2002). There are several studies about dimensions of perceived risk, such as Bhukya \& Singh (2015) which introduced four dimensions of perceived risk (psychological, financial, functional, and physical risk). Rotchanakitumnuai (2008) proposed five dimensions of perceived risk (performance, time, privacy, social, and financial risk). Thakur \& Srivastava (2014) introduced three dimensions of perceived risk (security, privacy, and monetary risk). This study examines five dimensions of perceived risk proposed by Rotchanakitumnuai (2008) because of its fit with the context of electronic government service. Performance risk defined as a risk that the electronic service will not work as what customer or user expected. Time risk is a risk that user feel that their wastes time as a result of making a wrong decision. Privacy risk is a risk that customer or user's fear that service provider will misuse their personal information. Financial audit risk refers to a risk that users have a potential to pay more money. And social risk is the potential risk faced by the user for status changes in a social group because of adopting a product or service (Rotchanakitumnuai 2008).

According to PWC (2014), when the customer does not ensure about their privacy online, they tend to be discouraged from transacting with a firm, which will reduce the rate to adopt internet banking (Chen \& Barnes 2007). Barua, Aimin, \& Akter (2016) and Tandon, Kiran, \& Sah (2017) found that perceived risk has a negative effect toward on satisfaction. Ltifi \& Gharbi (2012) stated that time risk has a negative effect on satisfaction, but financial risk, social risk, and functional risk has no effect on satisfaction. Based on the description above, we develop hypotheses as follow:

H1: Privacy risk has a negative effect on satisfaction.

$\mathrm{H} 2$ : Social risk has a negative effect on satisfaction.

H3: Performance risk has a negative effect on satisfaction.

H4: Financial audit risk has a negative effect on satisfaction.

H5: Time risk has a negative effect on satisfaction.

\subsection{Trust}

Trust is an important aspect for building and maintaining long-term relationships (Singh $\&$ Sirdeshmukh 2000). According to Corbitt et al. (2003), trust also a critical element in ecommerce (Corbitt et al. 2003). According to Chou, Chen, \& Lin (2015), when trust is 
formed, the customer is more likely to buying or repurchase an item from a website. Trust is defined as the trust level that citizen have on their government (Mofleh \& Wanous 2008).

According to Horppu et al. (2008), consumer trust is affected by customer satisfaction. The previous study suggests that customer satisfaction is an antecedent construct of trust, such as Bao, Li, Shen, \& Hou (2016) in e-commerce, Han \& Hyun (2015) in the medical tourism industry, and Lee, Moon, Kim, \& Yi (2015). Based on the description above, thus we developed a hypothesis as follow:

H6: Satisfaction has a positive effect on trust.

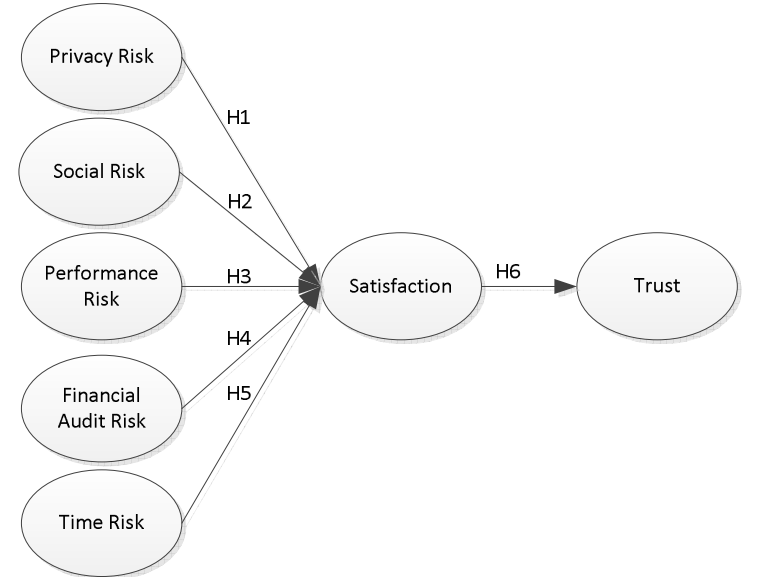

Fig.1. Conceptual Framework

\section{Method}

Data was collected via developed structured questionnaire. The target population is the user of X electronic government service in Jakarta, Tangerang, Depok, Bekasi, and Bogor area. The number of samples used is 200 , which determined by all the indicators times 10 (Hair et al. 2013). The sampling technique used is judgmental sampling with the criteria: the user of X electronic government service and lived in Jakarta, Tangerang, Depok, Bekasi, and Bogor area. There are 7 variables in this research i.e. time risk, financial audit risk, privacy risk, social risk and performance risk, satisfaction, and trust. Performance risk consists of 3 items. Privacy risk consists of 3 items. Social risk consists of 2 items. Time risk consists of 2 items. Financial Audit Risk consists of 3 items. All these variable adapted from Rotchanakitumnuai (2008). Satisfaction consists of 4 items adopted from Bhattacherjee (2001). Trust consists of 4 items adapted from Colesca (2009). All questions used 5 points in the Likert Scale. To test the hypotheses generated we used the Partial Least Square (PLSSEM) approach using SmartPLS version 3.0.

\section{Result \& Discussion}

\subsection{Respondent Profile}

In total, 100 percent of respondents have been using " $X$ " electronic government service. 40 percent of respondents are male and 60 percent are female. 1 percent of respondents were under 21 years old, 53.5 percent of respondents were between 21-30 years old, 34.0 percent of respondents were between 31-40 years old, 8 percent of respondents were between 41-50 years old, and 3.5 percent of respondents were over 50 years old. Of the total respondents 
surveyed, 57 percent of respondents were the first time using " $\mathrm{X}$ " electronic service and 43 percent were used " $\mathrm{X}$ " electronic service more than 1 time.

\subsection{Validity, Reliability And Discriminant Measurement Testing}

Validity and reliability testing were examined through confirmatory factor analysis (CFA). Reliability testing is done through composite reliability (CR) with a threshold of 0.7 . Validity testing is done through discriminant and convergent validity testing. Convergent validity was confirmed by examining standardized factor loading with 0.7 threshold and average variance extracted (AVE) with a threshold of 0.5 . To evaluate discriminant validity by comparing the value of square root of AVE for each variable. When conduct validity testing, there was 1 item has standardized factor loading below 0.7 (TS2) thus we deleted and recalculated the validity testing. Table 1 shows that all the indicators are valid, all AVE values were higher than 0.5 , and each CR of latent variables was higher than 0.7 , which all variables are reliable.

Table 1. Validity and Reliability Measurement

\begin{tabular}{|c|c|c|}
\hline $\begin{array}{l}\text { Constructs } \quad \& \\
\text { items }\end{array}$ & Outer Loading & $\begin{array}{l}\text { Remar } \\
\text { ks }\end{array}$ \\
\hline \multicolumn{3}{|c|}{ Performance Risk $(\mathrm{CR}=0.915, \mathrm{AVE}=0.782)$} \\
\hline PR1 & 0.880 & Valid \\
\hline PR2. & 0.889 & Valid \\
\hline PR3 & 0.885 & Valid \\
\hline \multicolumn{3}{|c|}{ Time Risk $(\mathrm{CR}=0,858, \mathrm{AVE}=0.753)$} \\
\hline TR1 & 0.776 & Valid \\
\hline TR2 & 0.951 & Valid \\
\hline \multicolumn{3}{|c|}{ Privacy Risk $(\mathrm{CR}=0.964, \mathrm{AVE}=0.898)$} \\
\hline PVR1 & 0.966 & Valid \\
\hline PVR2 & 0.968 & Valid \\
\hline PVR3 & 0,907 & Valid \\
\hline \multicolumn{3}{|c|}{ Social Risk $(\mathrm{CR}=0.893$, AVE $=0.808)$} \\
\hline SR1 & 0.821 & Valid \\
\hline SR2 & 0.971 & Valid \\
\hline \multicolumn{3}{|c|}{$\begin{array}{l}\text { Financial Audit Risk (C } \\
\text { 0.860) }\end{array}$} \\
\hline FR1 & 0.953 & Valid \\
\hline FR2 & 0.941 & Valid \\
\hline FR3 & 0.887 & Valid \\
\hline \multicolumn{3}{|c|}{ Satisfaction $(\mathrm{CR}=0.955, \mathrm{AVE}=0.843)$} \\
\hline SAT1 & 0.922 & Valid \\
\hline SAT2 & 0.933 & Valid \\
\hline SAT3 & 0.909 & Valid \\
\hline SAT4 & 0.907 & Valid \\
\hline \multicolumn{3}{|c|}{ Trust $(\mathrm{CR}=0.986, \mathrm{AVE}=0.959)$} \\
\hline TS2 & 0.975 & Valid \\
\hline TS3 & 0.983 & Valid \\
\hline TS4 & 0.980 & Valid \\
\hline \multicolumn{3}{|c|}{$\begin{array}{l}\text { Notes: } \text { AVE }=\text { average variance extracted, } C R= \\
\text { Composite Reliability. }\end{array}$} \\
\hline
\end{tabular}


Discriminant validity test shows that the value of square roots of average variance extracted was larger than the inter-construct correlation, which means all the requirements for the discriminant validity testing have been met.

\subsection{Hypotheses Testing Result}

After examining validity, reliability, and discriminant validity testing, we tested the proposed hypotheses. The results are presented in Table 3 . There were 3 hypotheses not significant because the t-statistic is less than $1.65(\mathrm{H} 2, \mathrm{H} 3$, and $\mathrm{H} 4)$. The other 3 hypotheses were significant because the t-statistic is more than $1.65(\mathrm{H} 1, \mathrm{H} 5$, and $\mathrm{H} 6)$.

Table 3. Hypotheses Testing Result

\begin{tabular}{llll}
\hline Hip & \multicolumn{1}{c}{ Path } & $\begin{array}{l}\text { t- } \\
\text { statistic }\end{array}$ & Result \\
\hline H1 & $\begin{array}{l}\text { Privacy Risk } \rightarrow \\
\text { Satisfaction }\end{array}$ & 2.605 & Supported \\
\hline H2 & $\begin{array}{l}\text { Social Risk } \rightarrow \\
\text { Satisfaction }\end{array}$ & 0.266 & $\begin{array}{l}\text { Not } \\
\text { supported }\end{array}$ \\
\hline H3 & $\begin{array}{l}\text { Performance Risk } \rightarrow \\
\text { Satisfaction }\end{array}$ & 1.246 & $\begin{array}{l}\text { Not } \\
\text { supported }\end{array}$ \\
\hline H4 & $\begin{array}{l}\text { Financial Audit } \\
\text { Risk } \rightarrow \text { Satisfaction }\end{array}$ & 0.541 & $\begin{array}{l}\text { Not } \\
\text { supported }\end{array}$ \\
\hline H5 & $\begin{array}{l}\text { Time Risk } \rightarrow \\
\text { Satisfaction }\end{array}$ & 1.909 & Supported \\
\hline H6 & Satisfaction $\rightarrow$ Trust & 8.189 & Supported \\
\hline
\end{tabular}

\section{Discussion}

This study contributes how perceived risk dimensions (time, financial audit, privacy, social, and performance risk) influence satisfaction and how satisfaction influence trust in the online context. This study shows privacy and time risk have a negative effect on satisfaction, but performance risk, social risk, and financial audit risk have no effect on satisfaction. The results of this study support the findings in literature time risk have a negative effect on satisfaction (Ltifi \& Gharbi 2012), privacy risk have a negative effect on satisfaction (Rotchanakitumnuai 2008), and also provided empirical evidence that satisfaction has a positive effect on trust (Bao et al. 2016; Han \& Hyun 2015; Lee et al. 2015).

Theoretically, this study provides additional literature on the dimensions of perceived risk that can be used to assess electronic government service initiative. Privacy risk and time risk affect customer satisfaction. However, performance risk, social risk, and financial audit risk have no effect on customer satisfaction.

The managerial implications of this research are government agencies as electronic service providers should focus on reducing privacy risk and time risk. Because a high privacy risk and time risk will affect customer satisfaction. To reduce privacy risk, the government needs to conduct a marketing campaign that ensures that users' personal data will not be misused and ensure the security of users' data information privacy. To reduce time risk, the government should review and if necessary simplifies the e-service procedures and makes it more user-friendly so the users do not feel that this e-service requires a lot of time. The results show that performance risk, social risk, and financial risk have no effect on satisfaction. The 
government does not need to worry about these three risks and only need to maintain these three risks. Satisfaction is important in shaping trust. Therefore, the government service provider needs to maintain and improve user satisfaction in order to increase their trust.

The limitations of this study are first, there was only five dimensions of perceived risk are used. It is better for the next research to add other dimensions of perceived risk such as psychology risk and convenience risk. Second, this research area is only limited to in Jakarta, Tangerang, Bogor, Depok, and Bekasi area, in the future it can be carried out in other areas outside in Jakarta, Tangerang, Bogor, Depok, and Bekasi area, like other major cities in Indonesia. Third, in the future research could add another variable, such as the intention to continue use.

\section{References}

[1] Anderson, R.E. \& Srinivasan, S.S., 2003. E-Satisfaction and E-Loyalty: A Contingency Framework. Psychology and Marketing, 20(2), pp.123-138.

[2] Bao, H. et al., 2016. Repurchase Intention in Chinese E-marketplace: Roles of Interactivity, Trust and Perceived Effectiveness of E-commerce Institutional Mechanisms. Industrial Management \& Data Systems, 116(8), p.

[3] Barua, Z., Aimin, W. \& Akter, S., 2016. The Influence Of Antecedents Of Perceived Risk On Satisfaction And Behavioral Intention Toward Self- Service Technologies : An Empirical Study. In 13th International Conference on Innovation and Management. pp. 19-31.

[4] Bhattacherjee, A., 2001. Understanding Information Systems Continuance: an Expectation - Confirmation Model. MIS Quarterly, 25(3), pp.351-370.

[5] Bhukya, R. \& Singh, S., 2015. The effect of perceived risk dimensions on purchase intention. American Journal of Business, 30(4), pp.218-230. Available at: http://www.emeraldinsight.com/doi/10.1108/AJB-10-2014-0055.

[6] Chen, Y.-H. \& Barnes, S., 2007. Initial trust and online buyer behaviour. Industrial Management \& Data Systems, 107(1), pp.21-36.

[7] Chou, S., Chen, C.-W. \& Lin, J.-Y., 2015. Female online shoppers: Examining the mediating roles of e-satisfaction and e- trust on e-loyalty development. Internet Research, 25(4), pp.542-561.

[8] Colesca, S.E., 2009. Increasing E-Trust: A Solution To Minimize Risk In EGovernment Adoption. journal of applied Quantitative Methods, 4(1), pp.1-16.

[9] Corbitt, B.J., Thanasankit, T. \& Yi, H., 2003. Trust and e-commerce: A study of consumer perceptions. Electronic Commerce Research and Applications, 2(3), pp.203215 .

[10] Cyr, D., Kindra, G.S. \& Dash, S., 2008. Web site design, trust, satisfaction and eloyalty: the Indian experience. Online Information Review, 32(6), pp.773-790.

[11] Featherman, M.S. \& Pavlou, P.A., 2003. Predicting e-services adoption: A perceived risk facets perspective. International Journal of Human Computer Studies, 59(4), pp.451-474.

[12] Hair, J.F., Black, W.C. \& Babin, B.J., 2013. Multivariate Data Analysis: A global perspective. 7th ed., United Kingdom: Pearson Education.

[13] Han, H. \& Hyun, S.S., 2015. Customer retention in the medical tourism industry: Impact of quality, satisfaction, trust, and price reasonableness. Tourism Management, 46(October), pp.20-29. Available at: http://dx.doi.org/10.1016/j.tourman.2014.06.003.

[14] Horppu, M. et al., 2008. Online satisfaction, trust and loyalty, and the impact of the 
offline parent brand. Journal of Product and Brand Management, 17(6), pp.403-413.

[15] Lee, D. et al., 2015. Antecedents and consequences of mobile phone usability: Linking simplicity and interactivity to satisfaction, trust, and brand loyalty. Information and Management, 52(3), pp.295-304. Available at: http://dx.doi.org/10.1016/j.im.2014.12.001.

[16] Ltifi, M. \& Gharbi, J.E., 2012. E-satisfaction and e-loyalty of consumers shopping online. Journal of Internet Banking and Commerce, 17(1), pp.1-20.

[17] Mofleh, S. \& Wanous, M., 2008. Understanding factors influencing citizens adoption of e-government services in the developing world: Jordan as a case study INFOCOMP. Journal of Computer Science, 7(2), pp.1-11.

[18] Papadopoulou, P. et al., 2001. Trust and relationship building in electronic commerce. Internet Research: Electronic Networking Applications and Policy, 11(4), pp.322-332.

[19] PWC, 2014. 2014 Ghana Banking Survey: The Future of Banking in Ghana...What's next?,

[20] Rotchanakitumnuai, S., 2008. Measuring E-government service value with the EGOVSQUAL-RISK model. Business Process Management Journal, 14(5), pp.724737.

[21] Shukla, P., 2014. The impact of organizational efforts on consumer concerns in an online context. Information and Management, 51(1), pp.113-119. Available at: http://dx.doi.org/10.1016/j.im.2013.11.003.

[22] Singh, J. \& Sirdeshmukh, D., 2000. Agency and Trust Mechanisms in Consumer Satisfaction and Loyalty Judgments. Journal of the Academy of Marketing Science, 28(1), pp.150-167.

[23] Tandon, U., Kiran, R. \& Sah, A.N., 2018. The influence of website functionality, drivers and perceived risk on customer satisfaction in online shopping: an emerging economy case. Information Systems and e-Business Management, 16(1), pp.57-91.

[24] Thakur, R. \& Srivastava, M., 2014. Adoption readiness, personal innovativeness, perceived risk and usage intention across customer groups for mobile payment services in India. IEmerald Insight Internet Research, 24(3), pp.369-392. Available at: http://www.emeraldinsight.com/10.1108/IntR-12-2012-0244.

[25] Warkentin, M. et al., 2002. Encouraging Citizen Adoption of e-Government by Building Trust. Electronic Markets, 12(3), pp.157-162. Available at: http://www.tandfonline.com/doi/abs/10.1080/101967802320245929. 